\title{
PERANAN ALAT BUKTI ELEKTRONIK DALAM TINDAK PIDANA PENCEMARAN NAMA BAIK
}

\author{
I Putu Angga Permana, I Made Arjaya, Ni Made Sukaryati Karma \\ Fakultas Hukum Universitas Warmadewa, Denpasar-Bali, Indonesia \\ anggapermana.ap17@gmail.com, imd.arjaya@gmail.com, madesukaryatikarma@gmail.com
}

\begin{abstract}
Abstrak
Penelitian ini mengkaji aturan-aturan terkait tindak pidana pencemaran nama baik berdasarkan Undang-undang Informasi dan transaksi elektronik, dan Menelaah proses pembuktian tindak pidana pencemaran nama baik dalam UU ITE. Penelitian ini menggunakan penelitian hukum empiris yaitu penelitian hukum yang melibatkan pengkajian penerapan hukum normatif dalam kasus peristiwa hukum tertentu yang ada dalam kehidupan masyarakat. Pendekatan yang digunakan adalah pendekatan perundang-undangan dan konseptual. Adapun data penelitian yaitu data primer dan sekunder yang diperoleh melelui teknik wawancara dan pencatatan, selanjutnya dianalisisi secara kualitatif. Hasil penelitian menunjukkan bahwa pengaturan berkenaan tindak pidana pencemaran nama baik dicantumkan dalam "UU. No.11/2008 pasal 5 ayat (1) dan (2) tentang Informasi dan Transaksi Elektronik" dimana kehadiran hukum baru ini menjadi sebuah pilihan solusi terkait kasus kriminal secara daring (cybercrime), Selanjutnya jika penggunaan alat bukti persidangan telah sesuai dengan peraturan yang ada di Indonesia, maka sebuah pembuktian tindak pidana, utamanya pencemaran nama baik dapat dikatakan sah. Adapun secara substansial, tindak pencemaran nama baik tegolong kedalam delik pidana maka perlu adanya jalan pembuktian apabila kasus yang terjadi bukanlah secara fisik melainkan lewat media daring (Cybercrime).
\end{abstract}

Kata kunci: Alat Bukti Elektronik, Pencemaran Nama Baik, Tindak Pidana

\section{Abstract}

This study is included in the category of empirical legal research carried out to fulfill the following objectives, 1) Assessing the rules related to criminal act of defamation in the Information and Electronic Transactions Law,

2) Examining the process of legal proof in criminal act of defamation under the Law of Information and Electronic Transactions. From the results of data analysis, it can be concluded that along with the increasing number of criminal cases through online media, the enforcement of electronic documents as legal evidence becomes very important due to the absence of physical evidence. The rules regarding the criminal act of defamation are included in the "Law. No.11 / 2008 article 5 paragraph (1) and (2) on Information and Electronic Transactions "where the presence of this new law is an enlightenment related to online criminal cases (cybercrime). Then, it was also found that only if the use of trial evidence was in accordance with the existing regulations in Indonesia, then proof of a criminal act, especially defamation, could be said to be legitimate. Substantially, defamation is classified as a criminal offense, so it is necessary to have a way of proof if the case occurred is not physically but through online media (Cybercrime).

Keywords: Electronic Evidence, Defamation, Criminal Acts

\section{PENDAHULUAN}

Saat ini, terlihat bahwa bahwa dunia tidak lagi memiliki batas karena mudahnya akses interaksi melalui media daring. Hal ini merupakan salah satu dampak perkembangan teknologi yang pesat. Tentu saja, secara tidak langsung, kondisi ini mempengaruhi juga perubahan masyarakat dalam berinteraksi, bernegara dan bertindak. Akses informasi yang mudah menjadikan keterbukaan sebagai hal lumrah dalam kehidupan masyarakat sekarang ini. Berinteraksi dengan individu lain di berbagai belahan dunia bukanlah hal yang tidak mungkin justru hadirnya teknologi membuat interaksi dibelahan duni menjadi mudah (Mahmudah, 2016). Dalam cara berkomunikasi terdapat beberapa sarana yang bisa dimanfaatkan oleh seseorang untuk mendapat ataupun menyebarkan informasi serta terus mengalami perkembangan dalam bentuk dan fungsi. Sarana yang dimaksud diantaranya, televisi, telegram, radio, faximile, telepon selular, serta internet yang dapat diakses dari manapun hari ini (Herawati, 2011).

Perkembangan fungsi jaringan internet sebagai sarana informasi tidak hanya dapat digunakan 
sebagai media interaksi namun juga dalam aktifitas lain seperti perdagangan atau biasa. Segala bentuk kegiatan baik berupa interaksi sosial ataupun kegiatan ekonomi seperti perniagaan melalui jaringan internet biasanya dijalankan oleh masyarakat melalui platform media sosial. Beberapa media sosial, utamanya di Indonesia, yang sedang popular diantaranya, Twitter, Facebook, Instagram, Telegram, Whatsapp, ataupun Club house.

Beriringan dengan terbukanya akses informasi lewat internet, dalam menyatakan pendapat dan sudut pandang terhadap sesuatu bagi masyarakat Indonesia juga mengalami kelonggaran dimana sebelumnya kita tidak bisa dengan mudah menyebarkan fikiran dan opini. Dalam praktiknya, banyak sekali kasus dimana seseorang melampaui batasan-batasan wajar dalam berpendapat meskipun kita sadar bahwa Indonesia merupakan negara hukum. Penerjemahan Indonesia sebagai Negara demokrasi dimana semua warga negara bebas mengutarakan pemikiran dan berpendapat kadangkala dimaknai dengan terlalu bebas (Jailani, 2015). Pendapat dan pemikiran yang dilontarkan seringkali melanggar hak-hak konstitusi pihak lain sebagai sesama warga negara sehingga menyebabkan kerugian bagi pihak tertentu. Tentu saja, jika dilihat dari kaca mata hukum, perilaku yang demikian merupakan pelanggaran terhadap norma. Bukanlah masalah jika individu ingin didengar pendapatnya, hanya saja pengutaraan pendapat tersebut haruslah tetap dalam koridor yang sesuai dengan norma yang diberlakukan di Indonesia. Tidak jarang, perilaku yang dilancarkan meninmbulkan permasalahan secara sosial bahkan secara hukum yang diantaranya termasuk kedalam tindak kejahatan.

Negara memang telah menjamin, dalam "TAP MPR NO. XVII tentang Hak Asasi Manusia" yang secara konstitusi dikuatkan lewat "amandemen UUD 1945" dan "Pasal 28 E ayat (2) UUD 1945; kemerdekaan berbicara, berekspresi dan kemerdekaan pers sebagai hak asasi setiap warga negara yang dianut oleh Indonesia sebagai negara demokrasi. Hanya saja dalam penerapan dan perlakuannya perlu diperhatikan batasan-batasan yang boleh dan tidak boleh sesuai norma yang dianut oleh masyarakat Indonesia. Kata kemerdekaan atau kebebasan tidak bisa dimaknai bahwa tidak ada pengecualian didalamnya.

Salah satu kasus pelanggaran terkait terlalu bebasnya pendapat yang disebarkan melauli platform media online adalah tindak pencemaran nama baik dimaan sesorang merusak citra baik seseorang atau suatu pihak lewat pendapatnya di platform daring. Tindakan ini lazim dilakukan oleh pihak-pihak yang tidak bertanggung jawab. Individu dikatakan melakukan tindak pencemaran nama baik jika melancarkan sebuah tuduhan atau penghinaan lewat pendapatnya secara langsung dan aktif kepada pihak lainnya yang bersangkutan atau memalui penyebaran pendapat dan ucapan tidak baik kepada seseorang lewat pihak lain dan mengarah pada penghinaan. Perbuatan yang dimaksud tidak langsung misalnya dengan penyebaran rumor, ataupun menyebarkan pendapat berupa informasi yang tercantum dalam media masa ataupun media daring.

Secara substansial, tindak pencemaran nama baik mencantum dan diatur dalam "Bab XVI KUHP Pasal 310 -Pasal 321 sebagai delik aduan. Tindakan terkait juga diatur dalam "UU.No. 1/ 2008 tentang Informasi dan Transaksi Elektronik (UU ITE)". Kemudian secara detail batasan-batasan yang diberlakukan terhadap tindakan yang dilarang diatur dalam "UU. ITE No.19/2016 Pasal 27 tentang perbuatan yang dilarang" dengan kriteria:

1. Setiap orang dengan sengaja dan tanpa hak mendistribusikan atau mentransmisikan dan/atau membuat dapat diaksesnya Informasi Elektronik atau Dokumen Elektronik yang memiliki muatan yang melanggar kesusilaan

2. Setiap orang dengan sengaja dan tanpa hak mendistribusikan atau membuat dapat diaksesnya informasi elektronik atau dokumen elektronik yang memiliki muatan perjudian

3. Setiap orang dengan sengaja dan tanpa hak mendistribusikan atau mentransmisikan dan/atau membuat dapat diaksesnya informasi elektronik atau dokumen elektronik yang memiliki muatan penghinaan atau pencemaran nama baik

4. Setiap orang dengan sengaja dan tanpa hak mendistribusikan atau mentransmisikan serta membuat dapat diaksesnya informasi elektronik dan/atau dokumen elektronik yang memiliki muatan pemerasan atau pengancaman

Keberadaan koridor yang telah ditetapkan dalam Undang-undang seharusnya cukup menjadi pengingat agar pengguna media sosial dapat menggunakan platform yang ada sebagaimana ketentuannya tanpa melanggar hak-hak orang lain dan sudah sepatutnya masyarakat meningkatkan kesadaran hukum dalam setiap tindakan yang dilakukannya. Meskipun tanpa aturan yang mengikat 
sepatutnya kita menjaga hak orang lain dengan tidak menyakiti apalagi menghina karena hal tersebut tidak berkesesuaian dengan norma yang dianut dalam negara Indonesia (Marzuki, 2010). Adanya, jerat hukum yang diatur terhadap pelanggaran pencemaran nama baik dapat menjadi pencegah agar perbuatan demikian tidak dilakukan (Ali, 2010). Dalam berinteraksi di media daring maupun di kehidupan sosial secara fisik seharusnya seseorang memegang teguh norma dan nilai-nilai yang sama karena, baik daring maupun luring, pihak yang berinteraksi dengan kita tetaplah manusia yang memiliki perasaan, hak, dan kepentingan yang harus diperhatikan juga. Berdasarkan uraian di atas maka, penelitian ini dilakukan dengan tujuan mengkaji aturan-aturan terkait tindak pidana pencemaran nama baik berdasarkan Undang-undang Informasi dan Transaksi Elektronik (UU ITE), dan Menelaah proses pembuktian tindak pidana pencemaran nama baik dalam UU ITE

\section{METODE PENELITIAN}

Penelitian ini didesai menggunakan penelitian hukum empiris. Secara definitif, yaitu penelitian hukum yang melibatkan pengkajian penerapan hukum normatif dam kasus peristiwa hukum tertentu yang ada dalam kehidupan masyarakat. Karena ini berkaitan pertauran, maka pendekatan yang digunakan yaitu pendekatan koseptual dan Perundang-undangan. Dengan begitu, penelitian ini merupakan studi langsung di lapangan dengan memanfaatkan data primer dan sekunder sebagai data pendukung. Dalam pengumpulan data, peneliti memanfaatkan berbagai macam instrument seperti, wawancara dan dokumentasi. Adapun wawancara yang ada dalam penelitian ini dilakukan di lingkungan Kepolisian Resor Tabanan terhadap jajaran pejabat kepolisian setempat. Dalam sifatnya yang kualitatif data dalam penelitian ini disusun dalam bentuk penjelasan deskriptif berkenaan isu dan kasus yang menjadi sasaran pengkajian.

\section{PEMBAHASAN HASIL PENELITIAN}

\section{Pengaturan Tindak Pidana Pencem aran Nama Baik}

Banyaknya manfaat yang diberikan oleh teknologi informasi dan elektronik memudah untuk menjalin hubungan sosial masyarakat di Indonesia. Dalam praktiknya, banyak sekali sektor, diantaranya, sektor perbankan, sektor industry, sektor perdagangan, bahkan pemerintahan menggunakan teknologi informasi dan elektronik sebagai alat bantu untuk memperlancar kegiatan (Parsaorantua et al., 2017). Namun, diluar semua manfaat baik yang dibawanya, tergantung cara penggunaan, teknologi dapat menjadi tidak tepat guna bahkan berujung menjadi sarana pelancaran (Cybercrime) tindak kriminalitas digital.

Praktik pelaksanaan tindak criminal jenis baru ini dapat dikatakan sebagai bentuk kejahatan dengan level tinggi yang akan sulit difahami oleh kelompok awam yang kurang mengerti teknologi karena didalamnya terdapat unsusr kepintaran dan juga penggunaan teknik-teknik canggih atau modus baru untuk melakukan kejahatan yang sebelumnya belum pernah dipakai. Karena adanya potensi kejahatan ini maka perlu ada aturan perundang undangan yang mengatur dan menjamin keamanan masyarak dalam melakukan transaksi dengan teknologi baik hanya untuk sekedar bertukar informasi ataupun melakukan kegiatan perekonomian secara digital (Zainal, 2010). Menjawab keperluan tersebut kemudian dirumuskan Undang-undang baru terkait informasi dan transaksi elektronik yang dikemudian hari lebih dikenal dengan UU ITE. Keberadaan payung hukum ini memberikan titik terang dan penjaminan keamanan bagi semua kalangan yang terlibat dalam kegiatan informasi dan transaksi elektronik untuk terlindungi dari berbagai macam potensi tindak kejahatan yang mungkin terjadi. Dengan kata lain, dapat dikatakan bahwa UU ITE merupakan sebuah upaya prefentif untuk mereduksi kemungkinan kemunculan kasus kejahatan yang disebabkan oleh penyalah gunaan teknologi informasi dan komunikasi. Selain itu hadirnya aturan tersebut juga dapat dipakai sebagai bentuk control terhadap perilaku masyarakat dalam bertransaksi secara elektronik (Fakhriah, 2009).

Dalam pasal 310 ayat 2 KUHP dibahas mengenai aturan-aturan berkenaan tindak pidana pencemaran nama baik. Sebagian ahli hukum berendapat bahwa itu sudah cukup sebagai alat untuk menjerat pelaku kejahatan terkait. Unsur pelaksanaan perbuatan yang diterangkan "dimuka umum, dan diketahui umum" tidak dapat diterapkan dalam tindakan melalui media daring karena prosesnya yang tidak terjadi secara fisik. Terkait dengan hal ini, maka MK memutuskan bahwa tidaklah cukup dengan pasal-pasal yang ada dalam KUHP untuk menangani masalah ini karena adanya unsur lain 
dalam kegiatan transaksi elektronik seperti penyebaran (distribusi), pemindahan (transmisi) informasi yang mengandung unsur pelecehan dan penghinaan secara digital yang tidak tercakup dalam pasalpasal yang telah diatur dalam kitab undang-undang hukum pidana. Oleh karena itu, mahkamah konstitusi, dalam putusannya menyatakan perlu ada aturan baru yang melingkupi area permasalahan baru yang terjadi akibat adanya kegiatan transaksi informasi secara digital yang lazim terjadi hari ini. Keputusan ini didasari pada pertimbangan bahwa pasal-pasal pidana yang ada dalam KUHP tidak cukup atau tidak menjangkau permasalahan hukum yang terjadi akibat kegiatan lewat media daring (Hamzah, 1987).

Berlandaskan pada putusan sebagaimana disebutkan di atas, maka dalam menjawab tantangan berkenaan perlindungan dan pejiaminan hukum bagi masyarakat dari tindak kejahatan digital utamanya yang bersangkutan dengan tindak pidana pencemaran nama baik, Mahkamah Konstitusi menetapkan untuk menerapkan "UU No.11/2008 tentang Informasi dan Transaksi Elektronik" dan tidak merujuk pada aturan yang diatur dalam pasal-pasala dalam Undang-Undang Hukum Pidana.

Berdasarkan hasil wawancara dengan Unit Reserse Kriminal Umum Polres Tabanan dengan BRIPKA I Dewa Gede Yasa Setiawan pada tanggal 4 Januari 2021, yang menyatakan bahwa: Pengaturan pencemaran nama baik sesuai UU ITE mempunyai keistimewaan apabila dibandingkan dengan pengaturan yang terdapat dalam KUHP. Secara praktis pengaturan tentang perbuatan yang dilarang berkaitan dengan tindak pidana pencemaran nama baik diatur dalam UU No.11 Tahun 2008 pada Bab VII tentang perbuatan yang dilarang; Pasal 27 ayat (3), Pasal 28 ayat (1) dan Pasal 36. Pasal 27 ayat (3) berbunyi Setiap Orang dengan sengaja dan tanpa hak mendistribusikan dan/atau mentransmisikan dan/atau membuat dapat diaksesnya informasi elektronik atau dokumen elektronik yang memiliki muatan penghinaan atau pencemaran nama baik. Yang dimaksud setiap orang dalam aturan tersebut adalah semua pihak tanpa terkecuali dalam statusnya sebagai subjek hukum. Kemudian bagian yang mengatakan dengan sengaja dan tanpa hak bias dimaknai sebagai segala macam tindakan yang melanggar aturan dan mengandung unsur kelalaian hukum dalam pelaksanaanya. Secara prosedural tindakan yang dimaksud melanggar dan mengandung unsur kelalaian hukum yang dimaksud adalah "mendistribusikan atau membuat dapat diakses informasi elektronik, dan/atau dokumen elektronik yang memiliki muatan penghinaan dan/atau pencemaran nama baik.

Delik perbuatan yang dimaksud dapat menjadi delik penuh jika tindak pidana yang muncul memenuhi secara utuh unsur pelaksanaan hal-hal yang telah dilarang. Dalam kondisi ini maka tindak pidana terkait merupakan delik yang sah masuk kedalam kategori pencemaran nama baik. Adanya situasi ini menjadikan pembuktian akan dampak dari tindakan yang dimaksud tidak diperlukan lagi karena semua unsur-unsur yang dilarang telah terpenuhi semuanya.

Terkait sanksi yang mengancam perbuatan pidana terkait tercantum dalam ketentuan dalam "Pasal 45 ayat (1) dalam Bab XI tentang ketentuan pidana yang berbunyi Setiap orang yang memenuhi unsur sebagaimana dimaksud dalam Pasal 27 ayat (1), ayat (2), ayat (3), atau ayat (4) dipidana dengan pidana penjara paling lama 6 (enam) tahun dan/atau denda paling banyak satu miliar rupiah, Kemudian, dalam Pasal 28 ayat (1) juga daitaur bahw Setiap Orang dengan sengaja dan tanpa hak menyebarkan berita bohong dan menyesatkan yang menyebabkan kerugian konsumen dalam transaksi elektronik.

Dalam situasi ini perbuatan yang mengandung unsur pelanggaran ini adalah rangkaian struktur kata, informasi atau cerita yang tersusun dengan memanfaatkan berbagai macam unsur penipuan didalamnya, hingga menimbulkan kesan bahwa benar adanya apa yang disampaikan meskipun sebenarnya hanya kebohongan belaka. Selanjutnya, tindakan yang mengandung unsur pelanggaran dan ketidakadilan tersebut mendapat ancaman hukuman pidana berdasarkan aturan Undang-undang dimana seorang individu merugikan pihak lain dalam transaksi elektronik.

Berdasarkan hasil wawancara yang dilakukan pada Unit Reserse Kriminal Umum Polres Tabanan dengan BRIPKA I Ketut Seregig pada tanggal 4 Januari 2021, yang menyatakan bahwa: Dengan diberlakukannya UU ITE maka terdapat suatu pengaturan yang baru mengenai alat-alat bukti dokumen elektronik dan transaksi elektronik merupakan sedikit kemajuan dalam menyikapi dan menanggulangi maraknya cybercrime saat ini, terutama dalam proses penegakan hukumnya/proses beracaranya. Pasal 5 ayat (1) dan (2) Undang-undang Nomor 11 Tahun 2008 tentang Informasi dan Transaksi Elektronik telah memberikan sedikit solusi atas kekosongan hukum acara pidana pada perkara-perkara cybercrime. 
Pemberlakuan UU ITE sebagai aturan baru dalam menangani permasalah hukum secara digital menuntut adanya bentuk alat-alat bukti hukum baru yang berkesesuaian dengan cakupanmasalah yang dilingkupo. Mengacu pada UU ITE Pasal 5 ayat 1 dijelaskan bahwa "informasi elektronik dan/atau dokumen elektronik dan/atau hasil cetaknya merupakan alat bukti hukum yang sah yang kemudian dalam UU ITE Pasal 5 ayat 2 dikatakan "informasi elektronik atau dokumen elektronik dan/ atau hasil cetaknya sebagaimana dimaksud pada ayat 1 merupakan perluasan alat bukti yang sah dan sesuai dengan hukum acara yang berlaku di Indonesia". Dalam kondisi ini, UU ITE secara formal telah menetapkan bahwa segala macam bentuk "dokumen elektronik dan/atau hasil cetaknya merupakan suatu alat bukti yang sah dan merupakan perluasan alat bukti yang sah sesuai dengan hukum acara yang telah berlaku di Indonesia" dan dapat dipakai sebagai alat bukti hukum untuk membantu proses peradilan tindak kejahatan pencemaran nama baik lewat media daring.

\section{Pembuktian Tindak Pidana Pencemaran Nama Baik dalam UU ITE}

Tindak pidana pencemaran nama baik suatu pihak dalam dunia maya umumnya dilakukan oleh pihakpihak tak bertanggungjawab dengan memanfaatkan beberapa cara dan platform digital. Berdasarkan hasil penelitian yang dilakukan pada Unit Reserse Kriminal Umum Polres Tabanan dengan BRIPKA I Ketut Seregig pada tanggal 4 Januari 2021 yang mengatakan bahwa, Individu dikatakan telah melanggar aturan terkait tidndak pidana pencemaran nama baik jika melakukan tindakan yang dilarang sebagaimana dimaksud dalam undang-undang secara aktif dan langsung. Ada pula orang yang melakukan pencemaran nama baik dengan mengungkapkan kata-kata yang tidak baik dan menyinggung mengenai seseorang kepada orang lain dan informasi tersebut didengar orang tersebut melalui desas-desus, atau melalui media massa dan media elektronik (Prakoso, 1988).

Hukum pidana berdasarkan materi yang diaturnya, terdiri atas hukum pidana materil dan hukum pidana formil. Hukum pidana materil merupakan isi atau substansi hukum pidana itu sendiri yang bermakna abstrak atau dalam keadaan diam, sedangkan hukum pidana formil bersifat nyata atau konkret, hukum pidana dalam keadaan bergerak, atau dijalankan atau berada dalam suatu proses. Sudah sepatutnya sebagai warga negara yang menganut faham hukum kita memelihara kesatuan negara dengan saling melindungi dan menjaga hak masing-masing. Seharusnya perkembangan teknologi yang pesat menjadikan kita bias memanfaatkannya sebagai sarana untuk menumbuhkembangkan rasa kebersamaan dan saling memiliki serta menghormati satu sama lain. Penerapan hukum seperti UU ITE pada dasarnya hanya sebagai bentuk penjaminan rasa aman dalam bertindak karena potensi dan bahkan bannyak terjadi bentuk-bentuk kejahatan baru secara daring akibat adanya perubahan pola tindakan masyarakat karena adanya perkembangan teknologi yang begitu pesat. Adapun faktor-faktor yang menyebabkan tindak pidana pencemaran nama baik, yaitu Kurangnya kesadaran dalam etika komunikasi sehingga seringkali kata-kata yang dilontarkan menyakiti bahkan merugikan pihak lai dan Tidak tahunya sebagian masyarakat bahwa tindakan menghina, meskipun hanya lewat platform daring memiliki ancaman hukuman pidana.

Hanya saja, meskipun dengan adanya potensi penyalahgunaan, semua pihak utamanya pemerintah sadar bahwa perkembangan teknologi informasi membawa manfaat besar dalam perkembangan kehidupan masyarakat dan perekonomian Negara. Dalam kondisi ini, bukanlah alasan untuk tidak mendukung pemanfaatan teknologi informasi karena adanya kemungkinan penggunaan yang tidak sesuai dan merugikan. Oleh karena itu, aturan dan sarana hukum diterapakn untuk menjamin keamanan dan pencegahan manfaat yang salah guna berdasar kepada nilai, asas, dan norma yang berlaku di Indonesia. Adapun, dalam pasal 310 ayat (1) KUHP diatur aturan hukum terkait dengan tindak pidana pencemaran nama baik, dimana didalamnya dijelaskan: Barang siapa dengan sengaja menyerang kehormatan atau nama baik seseorang dengan menuduhkan suatu hal, dengan maksud yang jelas agar hal itu diketahui umum, diancam karena pencemaran dengan pidana penjara paling lama 9 bulan atau pidana denda paling banyak Rp.4.500,00

Merujuk pada aturan yang tertera di atas maka perbuatan menghina atau mencemarkan nama baik dapat dimaknai dengan arti "menyerang kehormatan dan nama baik seseorang" yang menimbulkan rasa malu dan rusaknya citra diri seseorang di muka umum. Mengacu pada uraian sebelumnya bahwa kehormatan memiliki kedudukan sama dengan "rasa kehormatan" menurut teori De subjectieve opvatting. Kemudian, dalam sudut pandang laun kehormatan dapat berarti "rasa harga diri (eergevoel, perasaan terhormat) yang muncul dalam batin seseorang". Sehingga, "harga diri" adalah sesuatu yang bersifat perorangan atau personal. Sedangkan "nama baik" adalah persepsi yang 
tercipta dari luar pihak bersangkutan, social masyarakat, terkait dengan tindakan, penilaian, gambaran atau kedudukan dalam tatanan sosial

Pencemaran nama baik sudah masuk dalam delik perbuatan pidana. Baik dengan pasal penghinaan individu maupun pencemaran nama baik yang di atur dalam KUHP maupun UU ITE. Pelakunya harus di pidana, ini bukan hanya melanggar hukum, tapi juga etika dan moral. (wawancara dengan staf penyidik pada tanggal 7 Januari 202). Pemutusan penilaian dalam tindakan penghinaan atau pencemaran nama baik, pada dasarnya, bersifat subyektif dalam artian bahwa sebuah tindakan bias jadi pencemaran nama baik atau tidak tergantung sudut pandang pihak yang terkena dampak atau dialamatkan oleh tindakan dimaksud. Oleh sebab itu, proses hukum terkait masalah ini hanya dapat dijalankan jika ada pengaduan dari pihak yang merasa dirugikan, dihina atau dicemarkan nama baiknya karena kasus ini merupakan delik aduan.

Berdasarkan paparan di atas, dapat diketahui bahwa ukuran suatu perbuatan dapat dikategorikan sebagai pencemaran nama baik orang lain masih belum jelas karena banyak faktor yang harus dikaji. Dalam hal pencemaran nama baik atau penghinaan yang hendak dilindungi adalah kewajiban setiap orang untuk menghormati orang lain dari sudut kehormatannya dan nama baiknya dimata orang lain. Secara operasional pencemaran nama baik melalui media sosial adalah suatu tindakan yang dilakukan oleh seseorang atau oknum yang tanpa hak menyebarkan fitnah atau perkataan baik berupa video yang dapat menyerang kehormatan dan nama baik seseorang dan yang diserang itu biasanya merasa malu. Sehingga untuk mejatuhkan pidana terhadap seseorang yang diduga melakukan tindak pidana haruslah memenuhi syarat-syarat atau ketentuan pemidanaan sebagaimana yang diatur dalam Undang-undang yang berlaku.

\section{SIMPULAN DAN SARAN}

\section{Simpulan}

Berdasrkan hasil analisis data, dapat disimpulkan bahwa pengaturan berkenaan tindak pidana pencemaran nama baik dicantumkan dalam "UU. No.11/2008 pasal 5 ayat (1) dan (2) tentang Informasi dan Transaksi Elektronik" dimana kehadiran hukum baru ini menjadi sebuah pilihan solusi terkait kasus kriminal secara daring (cybercrime), Selanjutnya jika penggunaan alat bukti persidangan telah sesuai dengan peraturan yang ada di Indonesia, maka sebuah pembuktian tindak pidana, utamanya pencemaran nama baik dapat dikatakan sah. Adapun secara substansial, tindak pencemaran nama baik tergolong kedalam delik pidana maka perlu adanya jalan pembuktian apabila kasus yang terjadi bukanlah secara fisik melainkan lewat media daring (Cybercrime). Pelakunya harus di pidana, ini bukan hanya melanggar hukum, tapi juga etika dan moral. Dengan kata lain, bahwa alat bukti elektronik memiliki peran penting dalam pembuktian suatu tindak pidana khususnya tindak pidana pencemaran nama baik.

\section{Saran}

Ada beberapa saran yang diberikan terkait hasil penelitian di atas yaitu:

a. Aparat penegak hukum dan semua pihak terkait semestinya berperan secara aktif untuk mengedukasi masyarakat akan risiko yang ada dan segala hal yang terkait dengan tindakan penghinaan atau pencemaran nama baik.

b. Keberadaan dokumen elektonik sebagai alat bukti hukum memeiliki manfaat besar dalam investigasi tindak kejahatan digital yang terjadi. Diharapkan bahwa sistem yang sudah ada bisa dikembangkan lagi agar tidak terulang tindak kejahatan digital yang dapat merugikan. Selain itu, aturan-aturan mengenai hal-hal fundamental dalam pemanfaatan media daring dan teknologi elektronik pada umunya dapat diatur kembali secara seksama.

\section{DAFTAR PUSTAKA}

Ali, M. (2010). Pencemaran Nama Baik Melalui Sarana Informasi dan Transaksi Elektronik (Kajian Putusan MK No. 2/PUU-VII/2009). Jurnal Konstitusi, 7(6), 119-146.

Fakhriah, E. L. (2009). Bukti Elektromik dalam Sistem Pembuktian Perdata. Alumni. Bandung.

Hamzah, A. (1987). Aspek-aspek Pidana Dibidang Komputer. Sinar Grafika. Jakarta.

Herawati, E. (2011). Komunikasi dalam Era Teknologi Komunikasi Informasi. Humaniora, 2(1), $100-109$.

Jailani. (2015). Sistem Demokrasi di Indonesia Ditinjau dari Sudut Hukum Ketatanegaraan. Jurnal Inovatif, $8,1$. 
Mahmudah, D. (2016). Pengetahuan dan Pendapat Pemilih Pemula terhadap Akses Informasi Publik. Jurnal Studi Komunikasi Dan Media, 20(2), 241-258.

Marzuki, L. (2010). Konstitusionalisme dan Hak Asasi Manusia. Jurnal Konstitusi, 8(4), 479-488.

Parsaorantua, P. H., Pasoreh, Y., \& Rondonuwu, S. A. (2017). Implementasi Teknologi Informasi dan Komunikasi. Jurnal Acta Diurna, 6(3), 1-14.

Prakoso, D. (1988). Alat Bukti dan Kekuatan Pembuktian di dalam Proses Pidana. Liberty. Yogyakart.

Zainal, A. (2010). Pengantar dalam Hukum Pidana Indonesia. Jakarata. Yarsif Watampone. 